\title{
PENYULUHAN DAN EVALUASI PEMBUATAN KOMPOS LIMBAH RUMPUT LAUT (GRACILARIA SP. ) TERHADAP PERTUMBUHAN DAN PRODUKSI BAWANG MERAH (ALLIUM ASCALONICUM.L)
}

\author{
Extension And Evaluation Making Seaweed Waste Composition (Gracilaria Sp.) on \\ The Growth and Production Red Onion (Allium Ascalonicum. L) \\ Zaira Yuliantika ${ }^{1 *}$, Achmad Nizar $^{2}$ \\ Jurusan Penyuluhan Pertanian Berkelanjutan - Politeknik Pembangunan Pertanian Malang \\ Jl. Dr. Cipto 144A Lawang - Malang 65211 \\ email : factoipso5@gmail.com
}

\begin{abstract}
ABSTRAK
Penelitian bertujuan untuk mengetahui efektiftas penyuluhan dan peningkatan pengetahuan petani. Penelitian dilaksanakan di Desa Kabuaran Kecamatan Grujugan Kabupaten Bondowoso pada Bulan Januari sampai Bulan Maret 2019. Metode penyuluhan menggunakan ceramah, diskusi, dan demonstrasi cara. Sebelum penyuluhan, responden diberikan test awal (Pre-test) dan Tes Akhir (Post-Test) saat kegiatan penyuluhan selesai. Hasil penelitian menunjukkan efektifitas penyuluhan sebesar $77,2 \%$ dan peningkatan pengetahuan petani dengan prosentase $53,2 \%$.
\end{abstract}

Kata Kunci : Evaluasi; Efekivitas; Pengetahuan; Penyuluhan

\section{ABSTRACT}

The purposes of research were to know the effectiveness of counseling and increase knowledge of farmers. The study was conducted in Kabuaran Village, Grujugan Sub-District, Bondowoso Regency, in the Month of March 2019. Extension methods used lectures, discussions, and demonstrations on ways. Before extension start, the respondent was given the Pre-test and Post-Test when the extension activity was completed. The research showed that the effectiveness of counseling was $77.2 \%$ and the increase in farmers' knowledge was $53.2 \%$.

Keywords : Effectiveness; Evaluation; Extension; Knowledge 


\section{PENDAHULUAN}

Rukmana (1994) menyatakan bahwa bawang merah memiliki banyak sekali manfaat bagi kehidupan manusia sebagai obat tradisional seperti menyembuhkan luka atau infeksi, memperbaiki pencernaan dan menghilangkan lendir di tenggorokan.

Basmal (2009) menyatakan Rumput laut mengandung giberelin yang tidak hanya mendorong perpanjangan batang dan daun, tetapi juga terlibat dalam proses pengaturan perkembangan tumbuh seperti auksin. Auksin merupakan hormon pemacu protein yang terdapat pada membran plasma sel tumbuhan untuk memompa ion $\mathrm{H}+$ ke dinding sel. Untuk penyuluhan pembuatan Kompos Limbah Rumput Laut (Gracilaria Sp.) dan Evaluasi dilaksanakan di Desa Kabuaran Kecamatan Grujugan Kabupaten Bondowoso.

\section{METODE}

Pelaksanaan kegiatan ini dilakukan dengan cara mengkoordinasikan terlebih dahulu dengan kelompoktani tani makmur 7 Desa Kabuaran Kecamatan Grujugan Kabupaten Bondowoso terkait teknis dimana akan dilaksanakan kegiatan pekatihan ini. Sebelumpenyuluhan dilaksanakan, dilakukan Pre-Test terlebih dahulu. Setelah itu dimulai dengan pemberian penyuluhan metoda ceramah tentang keadaan lingkungan dan materi mengenai Kompos Limbah Rumput Laut (Gracilaria Sp.). Kemudian dilakukan demonstrasi cara serta diskusi mengenai pembuatan Kompos Limbah Rumput Laut (Gracilaria Sp.) dan diakhiri dengan PostTest.

\section{HASIL DAN PEMBAHASAN}

\section{Persiapan Penyuluhan}

Persiapan penyuluhan pertanian diawali dengan melakukan koordinasi dengan Penyuluh Desa Kabuaran dan Ketua Kelompoktani Tani Makmur 7 terkait dengan pelaksanaan penyuluhan seperti waktu, tempat serta sarana dan prasarana pelaksanaan penyuluhan serta demonstrasi cara. Sebelum melakukan penyuluhan terlebih dahulu membuat Lembar Persiapan Menyuluh (LPM), sinopsis, serta media berupa peta singkap dan folder.

\section{Kegiatan Penyuluhan}

Pelaksanaan penyuluhan yaitu pada hari Rabu, 27 Maret 2019 di rumah Ketua kelompoktani Tani Makmur 7, Desa Kabuaran, Kecamatan Grujugan, Kabupaten Bondowoso. Sebelum kegiatan penyuluhan dimulai, dilakukan tes awal (Pre-Test) yang pelaksanaannya 7 hari sebelum pelaksanaan penyuluhan yaitu pada hari Rabu, 20 Maret 2019. Adapun tujuan pelaksaan tes awal (Pre-Test) adalah agar dapat mengetahui tingkat pengetahuan petani dalam pengaplikasian kompos limbah rumput laut Glacilaria sp. Metode takakura pada pertumbuhan dan produksi bawang merah. Jumlah responden dalam tes awal (Pre-Test) adalah 
20 orang dengan jumlah pernyatan adalah 20 butir pernyataan.

\section{Materi Penyuluhan}

Materi penyuluhan yang disampaikan dalam pelaksanaan penyuluhan adalah hasil pelaksanaan kajian yang telah dilakukan sebelumnya. Adapun kajian yang telah dilakukan adalah "Pengaruh Pertumbuhan Bawang Merah (Allium Ascalonicum.L) Terhadap Pemberian Kompos Limbah Rumput Laut (Glacilaria sp.)" dalam pelaksanaan kajiann perlakuan terbaik dijadikan materi penyuluhan. Adapun perlakuan terbaik adalah Pemberian Kompos Limbah Rumput Laut (Glacilaria sp.) dosis 3 kg dengan penambahan POC Nasa/20cc.

Tujuan dan Sasaran Penyuluhan

Tujuan pelaksanaan penyuluhan pertanian adalah dapat meningkatnya pengetahuan petani dalam menggunakan Kompos Limbah Rumput Laut (Glacilaria sp.) dalam melakukan budidaya tanaman bawang merah. Dalam hal ini pelaku utama mau dan mampu memanfaatkan bahan-bahan organik seperti halnya limbah rumput laut yang dapat dimaan faatkan sebagai kompos dalam menunjanng usahatani.

Sasaran dalam pelaksanaan penyuluhan pertanian adalah petani bawang merah sebanyak 20 responden pada kelompoktani Tani Makmur 7 Ds Kabuaran, Kec. Grujugan, Kab. Bondowoso. Dilakukan penggalian identifikasi responden seperti umur, pendidikan terakhir dan lama berusahatani. Adapun data responden berdasarkan umur dapat dilihat pada tabel 1.
Tabel 1. Klasifikasi Umur Responden

\begin{tabular}{cccc}
\hline No & $\begin{array}{c}\text { Kisaran } \\
\text { Umur } \\
\text { (tahun) }\end{array}$ & $\begin{array}{c}\text { Jumlah } \\
\text { (orang) }\end{array}$ & $\begin{array}{c}\text { Presentase } \\
(\%)\end{array}$ \\
\hline 1. & $20-40$ & 14 & 70 \\
2. & $41-60$ & 4 & 20 \\
3. & $61-80$ & 2 & 10 \\
& Jumlah & 20 & $100 \%$ \\
\hline
\end{tabular}

Sumber : Data Primer Diolah, 2019

Pada tabel 1. Dapat diketahui bahwa presentasi terbanyak adalah $70 \%$ yang berarti bahwa responden terbanyak berumur 20-40 tahun dengan jumlah 14 orang dan presentasi $20 \%$ berjumlah 4 orang yang berumur 41-60 tahun. Sedangkan presentasi terendah adalah $10 \%$ berjumlah 2 orang dengan umur 61-80 tahun. Setelah menentukan presentase umur responden selanjutnya menentukan presentase pendidikan terakhir yang dimiliki responden. Adapun tingkat pendidikan terakhir responden dapat dilihat pada tabel 2 .

\section{Tabel 2. Klasifikasi Pendidikan}

Responden

\begin{tabular}{lccc}
\hline No & Pendidikan & $\begin{array}{c}\text { Jumlah } \\
\text { (orang) }\end{array}$ & $\begin{array}{c}\text { Presentase } \\
(\%)\end{array}$ \\
\hline 1. & SD & 14 & 70 \\
2. & SLTP & 4 & 20 \\
3. & SLTA & 2 & 10 \\
& Jumlah & 20 & $100 \%$ \\
\hline
\end{tabular}

Sumber : Data Primer Diolah, 2019

Pada tabel 2. Terdapat petani yang berpendidikan terakhir SD, SLTP, dan 
SLTA. Petani terbanyak berpendidikan terakhir pada jenjang SD sebanyak 14 orang dengan presentase $70 \%$, sedangkan SLTP 4 orang dengan presentasi $20 \%$ dan SLTA 2 orang dengan presentasi $10 \%$. Sebagian besar petani memliki latar pendidikan yang baik sehingga mampu menerima dan menyerap adopsi inovasi untuk diaplikasikan di lahan usahataninya. Selain umur dan pendidikan terakhir perlu juga melakukan identifikasi lama berusahatani responden sebagaimana pada tabel 3.

Tabel 3. Klasifikasi Lama Berusahatani Responden

\begin{tabular}{cccc}
\hline No & $\begin{array}{c}\text { Lama } \\
\text { Berusahatani } \\
\text { (tahun) }\end{array}$ & $\begin{array}{c}\text { Jumlah } \\
\text { (orang) }\end{array}$ & $\begin{array}{c}\text { Presentase } \\
(\%)\end{array}$ \\
\hline 1. & $1-10$ & 7 & 35 \\
2. & $11-20$ & 7 & 35 \\
3. & $21-30$ & 3 & 15 \\
4. & $31-40$ & 2 & 10 \\
5. & $41-50$ & 0 & 0 \\
6. & $51-60$ & 1 & 5 \\
& Jumlah & 20 & $100 \%$
\end{tabular}

Sumber : Data Primer Diolah, 2019

Pada tabel 3. Petani sudah berusahatani mulai dari 1-60 tahun. Berdasarkan presentasi yang ada jumlah terbanyak adalah 1-10 dan 11-20 tahun sebanyak 7.orang dengan presentasi yang sama yaitu sebesar 35\%. Presentasi terendah adalah 5\% dengan jumlah petani 1 orang petani dengan lama berusaha tani 51-60 tahun.

\section{Metoda Penyuluhan}

Metode penyuluhan pertanian yang digunakan adalah ceramah, diskusi dan demonstrasi cara. Dalam pelaksanaan penyuluhan menggunakan metoda ceramah untuk memberikan materi penyuluhan kepada responden terkait dengan Pengaruh Pertumbuhan Bawang Merah (Allium Ascalonicum.L) Terhadap Pemberian Kompos Limbah Rumput Laut (Glacilaria sp.). Demonstrasi cara dilakukan pada kegiatan penyuluhan guna melakukan pengembangan teknologi baru dalam pembuatan Kompos dari Limbah Rumput Laut (Glacilaria sp.) dimulai dari persiapan alat bahan, langkah-langkah pembuatan dan pengaplikasian Kompos Limbah Rumput Laut pada bawang merah.

Pelaksanaan diskusi dilakukan setelah pelaksanaan penyuluhan serta demonstrasi cara untuk memberikan kesempatan kepada responden untuk bertanya hal-hal yang belum jelas atau belum dimengerti selama kegiatan penyuluhan pertanian berlangsung. Penyaji diharuskan menjawab pertanyaan yang diberikan responden dengan baik dan jelas. Responden diharapkan mampu memahami pelaksanaan penyuluhan sehingga tujuan dari penyuluhan dapat tercapai.

\section{Media Penyuluhan}

Media yang digunakan dalam pelaksanaan penyuluhan adalah peta singkap dan folder. Menggunakan peta singkap agar responden lebih memahami materi yang disampaikan dan lebih tertarik mengikuti pelaksanaan penyuluhan. 
Adapun menggunakan folder dalam penyuluhan pertanian agar petani lebih mudah memahami materi yang disampaikan selain itu juga menggunakan media alat dan bahan dalam pelaksanaan demonstrasi cara pembuatan Kompos Limbah Rumput Laut.

Hasil Pelaksanaan Evaluasi dan Pembahasan Evaluasi Pengetahuan Petani

Test awal (Pre-Test) dilakukan sebelum kegiatan penyuluhan pertanian yang dilaksanakan 7 hari sebelum pelaksanaan penyuluhan yaitu pada hari Rabu, 20 Maret 2019. Tujuan dari pelaksanaan Test awal (PreTest) adalah agar dapat mengetahui tingkat pengetahuan petani dalam pengaplikasian kompos limbah rumput laut Glacilaria $s p$. Metode takakura pada pertumbuhan dan produksi bawang merah. Jumlah responden dalam tes awal (Pre-Test) adalah 20 orang dengan jumlah pernyatan adalah 20 butir pernyataan.

Test akhir (Post-Test) dilakukan setelah kegiatan penyuluhan pertanian guna mengetahui tingkat pengetahuan petani dalam pengaplikasian kompos limbah rumput laut Glacilaria sp. Metode takakura pada pertumbuhan dan produksi bawang merah.

Dalam pelaksanaan evaluasi terdapat 20 responden dengan 20 butir pertanyaan. Dari hasil pelaksanaan evaluasi nilai Test awal (Pre-Test) adalah 1368. Sedangkan nilai Test akhir (Post-Test) mencapai 1544. Sehingga terjadi peningkatan pengetahuan setelah penyuluhan mencapai 292.
Peningkatan hasil rekapitulasi tes awal (Pre-Test) dan test akhir (Post-Test) menunjukkan adanya peningkatan pengetahuan petani terkait penyuluhan yang sudah dilakukan. Materi penyuluhan yang diberikan kepada petani dapat diterima dengan baik sehingga mampu menambah pengetahuan yang dimiliki petani terutama dalam melakukan budidaya bawang merah dengan pengaplikasian kompos limbah rumput laut Glacilaria sp.

\section{Efektifitas Penyuluhan}

Pelaksanaan penyuluhan di rumah Ketua kelompoktani Tani Makmur 7 , Desa Kabuaran, Kecamatan Grujugan, Kabupaten Bondowoso dengan 20 responden diperoleh efektifitas penyuluhan sebagai berikut:

$$
\frac{\sum N . \text { Posttest }}{T \arg e t} \times 100 \%
$$

$$
\frac{1544}{2000} \times 100 \%=77,2 \%
$$

Menurut Ginting dalam Susanto (2014), kriteria nilai efektifitas adalah sebagai beikut :

Kurang Efektif $\quad:<33,3 \%$

Cukup Efektif $\quad: 33,3 \%-66,6 \%$

Efektif : $>66,6 \%$

Efektif penyuluhan yang dilakukan untuk mengukur pengetahuan petani terkait dengan materi pengaplikasian kompos limbah rumput laut Glacilaria sp. Metode takakura pada bawang merah mencapai $77,2 \%$ yang tergolong dalam kriteria nilai efektifitas "Efektif". Dalam 
pelaksanaan penyuluhan menggunakan media peta singkap dan folder serta metoda ceramah, diskusi, dan demonstrasi cara dapat berpengaruh terhadap perubahan pengetahuan petani.

\section{Peningkatan Pengetahuan}

Pengamatan pada kapasitas pengetahuan petani sebelum dilakukan penyuluhan pertanian menunjukkan hasil yang rendah. Namun setelah dilakukan kegiatan penyuluhan maka terdapat peningkatan pengetahuan responden sebagai berikut:456

$$
\frac{\sum \text { posttest }-\sum \cdot \text { pretest }}{T \arg e t-\text { pretest }} \times 100 \%
$$

$$
\frac{292}{548} \times 100 \%=53,2 \%
$$

Adapun kriteria tingkat pengetahuan adalah sebagai berikut :

- Kurang : :20-40

- Cukup : :41-60

- Baik : $61-80$

- Sangat baik : $\quad 81-100$

Peningkatan pengetahuan petani setelah penyuluhan mencapai 53,2 \% sehingga dapat dikatakan pengingkatan pengetahuan petani tergolong "Cukup" sehingga petani mampu memiliki pengetahuan yang lebih luas terkait dengan pengaplikasian kompos limbah rumput laut Glacilaria sp. Metode takakura dalam pertumbuhan maupun peningkatan produksi bawang merah.
A. Peningkatan
Pengetahuan
Berdasarkan Usia

Peningkatan pengetahuan petani responden dapat dilihat melalui perbandingan antara Pre -Test dan PostTest. Hal ini merupakan akibat langsung (Feed back) dari proses penyuluhan yang dilakukan. Sebelum melaksanakan penyuluhan responden diberikan kuesioner atau Pre-test dengan tujuan untuk mengukur tingkat pengetahuan dasar. Sedangkan Post-Test dilakukan setelah pelaksanaan penyuluhan dengan tujuan untuk mengetahui daya serap responden terhadap materi penyuluhan yang diberikan. Peningkatan pengetahuan petani berdasarkan strata usia dapat dilihat pada tabel 4 .

\begin{tabular}{|c|c|c|c|c|c|c|c|}
\hline \multirow[t]{2}{*}{ No } & \multirow{2}{*}{$\begin{array}{l}\text { Strata Usia } \\
\text { (Th) }\end{array}$} & \multirow{2}{*}{$\begin{array}{l}\text { Jumlah } \\
\text { Orang }\end{array}$} & \multicolumn{2}{|c|}{$\begin{array}{c}\text { Rata - rata Nilai } \\
\text { Tes wal }\end{array}$} & \multicolumn{2}{|c|}{$\begin{array}{l}\text { Rata - rata Nilai } \\
\text { Tes Akhir }\end{array}$} & \multirow{2}{*}{$\begin{array}{c}\text { Persentasi } \\
\text { peningkatan } \\
\text { Skor Nilai (\%) }\end{array}$} \\
\hline & & & Nilai & Kategori & Nilai & Kategori & \\
\hline 1 & $20-40$ & 14 & 68 & baik & 86,2 & sangat baik & 15,3 \\
\hline 2 & $41-60$ & 4 & 66 & baik & 85 & sangat baik & 15,2 \\
\hline 3 & $61-80$ & 2 & 52 & cukup & 86 & sangat baik & 13,8 \\
\hline & Jumlah & 20 & & & & & \\
\hline
\end{tabular}

Tabel 4. Peningkatan Pengetahuan Berdasarkan Usia

Sumber : Data Primer Diolah, 2019

Pada tabel 4. Peningkatan pengetahuan 
berdasarkan usia tertinggi mencapai 15,3\% usia 20-40 sedangkan peningkatan usia terendah $13,8 \%$ pada usia $61-80$. Peningkatan pengetahuan tertinggi terdapat pada usia yang produktif. Petani yang masih berusia muda mempunyai tingkat partisipasi tinggi karena cenderung masih memiliki rasa ingin maju sehingga kurang memperhatikan resiko yang akan dialami kedepannya. Tingkat umur yang masih produktif sangat mempengaruhi kemampuan seseorang dalam menyerap inovasi dan mudah mengambil keputusan dalam penerapan inovasi.

Menurut Soekartawi (1988) dalam Sari J, dkk (2015) umur petani mempengaruhi kemampuan kerja fisik dan kematangan psikologisnya. Petani setengah baya cenderung yang paling tinggi adopsi inovasinya, karena kekuatan fisik dan kematangan psikologisnya saling mendukung.

B. Peningkatan Pengetahuan

Berdasarkan Tingkat Pendidikan

Mengetahui peningkatan pengetahuan responden berdasarkan pendidikan dapat dilihat pada tabel 5 .

Tabel 5. Peningkatan Pengetahuan

Berdasarkan Pendidikan

\begin{tabular}{|c|c|c|c|c|c|}
\hline \multirow[t]{2}{*}{ No } & \multirow[t]{2}{*}{$\begin{array}{c}\text { Tingkat } \\
\text { Pendidikan }\end{array}$} & \multirow[t]{2}{*}{$\begin{array}{l}\text { Jumlah } \\
\text { Orang }\end{array}$} & \multicolumn{2}{|c|}{$\begin{array}{c}\text { Rata - rata Nilai } \\
\text { Tes wal }\end{array}$} & $\begin{array}{r}\text { Rata - rata Nilai Tes Akhir } \begin{array}{c}\text { Persentase } \\
\text { SIMPULAN }\end{array} \\
\text { peningkatan }\end{array}$ \\
\hline & & & Nilai & Kategori & Nilai Kategori Skor Nilai (\%) \\
\hline 1 & SD & 14 & 61,4 & Baik & \multirow{4}{*}{ 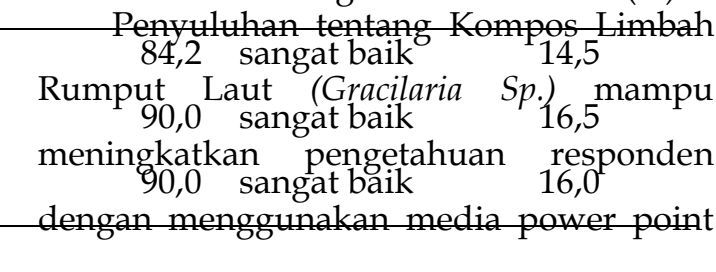 } \\
\hline 2 & SLTP & 4 & 75,0 & Baik & \\
\hline 3 & SLTA & 2 & 70,0 & Baik & \\
\hline & Jumlah & 20 & & & \\
\hline
\end{tabular}

pengetahuan berdasarkan pendidikan tertinggi pada petani yang menempuh pendidikan SLTP sebesar 16,5\% Peningkatan terendah mencapai 14,5\% pada pendidikan SD. Latar belakang pendidikian sangat mempengaruhi tingkat adopsi inovasi teknologi. Hal ini meunjukkan dari hasil prosentasi peningkatan skor nilai petani responden dengan tingkat pendidkan SLTP dan SLTA lebih tinggi dibandingkan dengan petani responden yang berpendidkan SD. Tetapi tingkat adopsi inovasi teknologi dalam penyuluhan tidak selamanya dipengaruhi oleh tingkat pendidikan, karena tingkat konsentrasi dan minat dari peserta juga sangat dipengaruhi dalam penerapan suatu inovasi teknologi usahatani.

Menurut Sari J dan dkk (2015) lama pendidikan petani memiliki kontribusi secara langsung terhadap peningkatan pengetahuan petani terhadap adopsi inovasi. Hasil ini sejalan dengan penelitian Ardiansyah (2014) bahwa semakin tinggi tingkat pendidikan petani maka semakin tinggi pula kapasitas peningkatan pengetahuannya.

Sumber : Data Primer Diolah, 2019 
dan folder serta metoda ceramah, diskusi dan demonstrasi cara.

Tingkat Pengetahuan petani mencapai $53,2 \%$ yang tergolong dalam kriteria "Cukup" dan efektivitas penyuluh mencapai 77,2\% yang tergolong dalam kriteria "Efektif. Sehingga pelaksanaan penyuluhan yang dilakukan dapat meningkatkan pengetahuan petani dalam pengaplikasian Kompos Limbah Rumput Laut (Gracilaria Sp.) pada pertumbuhan dan Produksi Bawang Merah.

\section{DAFTAR PUSTAKA}

Ardiansyah A, Gitosaputro S, dan Yanfika H. 2014. Persepsi Petani Persepsi Petani Terhadap Kinerja Penyuluh di BP3K Sebagai Model Center Of Excellence (CoE) JIIA: 2(2): 182-189.

Azyyati,R,dkk.2016.Respon Pertumbuhan dan Produksi Bawang Merah Terhadap Dosis Pupuk Organik Cair Titonia dan Interval Waktu Pemberian.Medan:USU.

Basmal J, et al. 2009. Mekanisasi proses pengeringan dan sistem pemisahan filtrat rumput laut. Laporan Akhir Penelitian Mekanisasi Proses. Balai Besar Riset Pengolahan Produk dan Bioteknologi Kelautan dan Perikanan.

Hutchison, et al. 2002. Cytokinin signaling in arabidopsis. Biology Department, University of North Carolina, Chapel
Hill, North Carolina 27599-3280.

The Plant Cell, S47-S59, Supplement 2002.

Rezagama A. 2015. Studi Optimasi Takakura Dengan Penambahan Sekam Dan Bekatul. Jurnal Presipitasi. Program Studi Teknik Lingkungan Fakultas Teknik Universitas Diponegoro. Vol. 12 No. 2.

Rukmana, R. 1994. Bawang Merah, Budidaya Dan Pengolahan Pascapanen. Penerbit Kanisius Yogyakarta.

Sari J, Indah N, dan Helvi Y. 2015. Persepsi Petani Terhadap Kinerja Penyuluh Dalam Pengembangan Padi Organik Di Kecamatan Pagelaran Kabupaten Pringsewu. Jurusan Agribisnis, Fakultas Pertanian, Universitas Lampung. JIIA, VOLUME 3 No. 4.

Yunizal. 2014. Teknologi Pengolahan Alginat. Badan Riset Kelautan dan Perikanan. 